\title{
Warunki stosowania w Polsce umorzeń płatności należności budżetowych
}

Przepisy prawa obowiązujące w Polsce, w szczególności ustaw: $\mathrm{z}$ dnia 27 sierpnia 2009 r. o finansach publicznych (dalej: ustawa ${ }^{1}$ ) oraz z 29 sierpnia 1997 r. Ordynacja podatkowa (dalej: o.p. ${ }^{2}$ ), zezwalają na stosowanie ulg w płatności zobowiązań o charakterze publicznoprawnym i cywilnoprawnym. Mowa tutaj w szczególności o podatkach, niepodatkowych należnościach budżetowych i należnościach pieniężnych o charakterze cywilnoprawnym - art. 55, 60 ustawy i art. 67a o.p.

Konieczność istnienia unormowań tego rodzaju stanowi następstwo faktu, iż w określonych sytuacjach zobowiązany, niezależnie od statusu formalnoprawnego, który posiada, ma prawo oczekiwać od organu odpowiedzialnego za wymiar i pobór świadczenia, iż złagodzi ciążące na nim zobowiązania finansowe ${ }^{3}$. Przepisy prawa finansowego nie są bowiem w stanie przewidzieć i uwzględnić wszystkich sytuacji, w jakich może się znaleźć zobowiązany do zapłaty ${ }^{4}$. W praktyce oznacza to, że ww. organ ustali dogodniejsze warunki zapłaty, zredukuje ich wymiar, a nawet zwolni zobowiązanego całkowicie od obowiązku zapłaty5. To ostatnie ma miejsce w przypadku podjęcia decyzji o umorzeniu pełnej kwoty zobowiązania oraz ewentualnych odsetek za zwłokę. Dotychczasowa praktyka ustawodawcza wskazuje, że ulgi ${ }^{6} \mathrm{~W}$ płatnościach zobowiązań publicznoprawnych

* Prof. nadzw. dr hab. Marek Zdebel - Katedra Prawa Finansowego, Wydział Prawa i Administracji, Uniwersytet Śląski.

1 Dz. U. Nr 157, poz. 1240.

2 Dz. U. Nr 137, poz. 926 ze zm.

${ }^{3} \mathrm{Na}$ istnienie takich uwarunkowań w zakresie wykonywania zobowiązań podatkowych powołuje się P. Pomorski, System ulg w splacie należności podatkowych w świetle przepisów ordynacji podatkowej, [w:] B. Kucia-Guściora, M. Munnich, L. Bielecki, A. Krukowski (red.), Ordynacja podatkowa w teorii i praktyce, Lublin 2008, s. 9.

${ }^{4} \mathrm{~W}$ odniesieniu do zobowiązań podatkowych podkreśla to S. Presnarowicz, Ulgi i zwolnienia uznaniowe w ordynacji podatkowej, Warszawa 2002, s. 13.

${ }^{5}$ Zdaniem W. Nykiela w przypadku, gdy umorzenie dotyczy całej należności podatkowej (podatku, odsetek zwłoki, opłaty prolongacyjnej) bardziej uprawnione jest posługiwanie się wyrażeniem „Zwolnienie z zapłaty podatku” - por. W. Nykiel, Ulgi i zwolnienia w konstrukcji podatku, Warszawa 2002, s. 31.

${ }^{6}$ Ulgi, o których mowa, należy odróżniać od ulg traktowanych jako samoistny element konstrukcyjny podatku, definiowany przepisem art. 3 pkt 6 o.p. 
i cywilnoprawnych przybierają najczęściej postać umorzenia zobowiązania, odroczenia terminu jego zapłaty oraz rozłożenia płatności na raty. Zastosowanie którejkolwiek z tych ulg, mimo że w różnym stopniu kształtują one sytuację finansową zobowiązanego, oznacza odstępstwo od ogólnych zasad wykonywania zobowiązań7. W tym miejscu należy jednak zauważyć, że całkowite umorzenie zobowiązania nie prowadzi do wykonania wymagalnego zobowiązania, lecz powoduje $\mathrm{w}$ przypadku zobowiązań publicznoprawnych ich wygaśnięcie ${ }^{8}$ bądź zwolnienie z długu w przypadku należności cywilnoprawnych ${ }^{9}$. Natomiast ulga odroczenia spłaty należności pieniężnej polega zasadniczo na wydłużeniu terminu do zapłaty należności, zaś rozłożenie płatności na raty - na podzieleniu kwoty należności na co najmniej dwie części i ustaleniu dla każdej z nich odrębnych terminów płatności. Skutkiem zastosowania tych ostatnich ulg nie jest zatem rezygnacja z należności pieniężnej, lecz odpowiednio zgoda na zapłatę całości zobowiązania $\mathrm{w}$ terminie późniejszym lub zapłatę zobowiązania w częściach w terminie późniejszym niż termin wynikający z obowiązujących przepisów ${ }^{10}$. Ulga polegająca na umorzeniu występuje zatem, podobnie jak odroczenie terminu płatności i rozłożenie płatności na raty, obok ulg systemowych będących elementem konstrukcyjnym danego podatku ${ }^{11}$, lecz w odróżnieniu od nich posiada charakter nadzwyczajny, gdyż zasadą jest zapłata zobowiązań i niezwalnianie zobowiązanych od tego obowiązku ${ }^{12}$.

Ustawowa dopuszczalność zastosowania umorzenia zobowiązania (w całości bądź w części) na wniosek zobowiązanego, w sytuacji gdy oznacza ono z finansowego punktu widzenia rezygnację ze środków publicznych w rozumieniu art. 5 ustawy, skłania do podjęcia próby ustalenia warunków jej stosowania. Poruszenie tej problematyki uzasadnione jest także tym, że zgodnie z brzmieniem art. 216 Konstytucji $\mathrm{RP}^{13}$ środki publiczne są gromadzone $\mathrm{i}$ wydatkowane wyłącznie w sposób określony w ustawie, a więc modyfikowanie zasad ich poboru jest możliwe tylko w przypadkach i w zakresach wyraźnie określonych w ustawie ${ }^{14}$.

${ }^{7}$ Por. S. Presnarowicz, Ulgi i zwolnienia uznaniowe..., s. 13.

${ }^{8} \mathrm{~W}$ pierwszym rzędzie dotyczy to zobowiązań podatkowych - por. M. Zdebel, Public interest as a prerequisite for remission of tax obligations, „Silesian Journal of Legal Studies”, Contents vol. 3, s. $101 \mathrm{i} \mathrm{n.}$

${ }^{9}$ Por. R. Szostak, Udzielanie ulg w spłacie należności cywilnoprawnych przyshugujących jednostkom samorzadu terytorialnego, „Samorząd Terytorialny” 2011, nr 6, s. 54.

${ }^{10}$ Por. I. Lipiec-Warzecha, Komentarz do art. 55 ustawy o finansach publicznych, s. 1, http:// lex.bg.us.edu.pl/lex/content.rpc?regld=13214628505756\&nr.

${ }_{11}$ Por. M. Popławski, Charakter ulg $i$ zwolnień podatkowych będacych pomoca publiczna, „Monitor Podatkowy” 2005, nr 7, s. 31.

${ }_{12}$ Por. wyrok SN z dnia 15 maja 1991 r., SA/Gd 295/91, „Przegląd Orzecznictwa Podatkowego" 1994, nr 1, poz. 7.

${ }^{13}$ Ustawa z dnia 2 kwietnia 1997 r. Konstytucja Rzeczypospolitej Polskiej, Dz. U. Nr 78, poz. 483.

$14 \mathrm{~W}$ przypadku należności cywilnoprawnych zgodnie z przepisami ustawy - por. R. Szostak, op. cit., s. 48. 
Analiza wskazanej problematyki może być realizowana na podstawie różnych kryteriów. Do najważniejszych, choć niewątpliwie najtrudniej poddających się ocenie, należy kryterium ustawowych warunków-przesłanek stosowania umorzenia zobowiązań (dalej: ulga). Z uwagi na wielowątkowość podjętej problematyki, przede wszystkim zaś fakt, iż na gruncie przepisów art. 55-59 ustawy oraz art. 67a i n. o.p. można wyodrębnić zarówno przesłanki materialne, jak i formalne. Kolejność rozważań zawartych w opracowaniu dostosowano do zasygnalizowanego podziału przesłanek. W tym miejscu wskazać jednak należy, iż mimo różnic występujących pomiędzy regulacjami prawnymi dotyczącymi umarzania należności publicznoprawnych i należności cywilnoprawnych, w odniesieniu do obu uzasadnione jest wykorzystanie dorobku nauki i orzecznictwa sądowoadministracyjnego w zakresie ulg w płatności zobowiązań podatkowych ${ }^{15}$. Przemawia za tym przede wszystkim to, że ulgi w płatności tych zobowiązań przybierają generalnie taką samą postać (za wyjątkiem zaniechania ustalenia i poboru należności podatkowej - art. 22 o.p. ${ }^{16}$ ). Ponadto, ich stosowanie opiera się na wystąpieniu tożsamych przesłanek ustawowych oraz uznaniowym charakterze decyzji podejmowanych przez organy uprawnione do ich udzielania.

Z uwagi na zróżnicowany charakter prawny należności pieniężnych, wobec których ulga może być stosowana, w pierwszym rzędzie niezbędne staje się ustalenie znaczenia pojęć: ,podatkowa należność budżetowa, „niepodatkowa należność budżetowa” oraz „,należność o charakterze cywilnoprawnym”. Stosunkowo najprościej wyjaśnić pierwsze $\mathrm{z}$ wymienionych pojęć albowiem ustawodawca zawarł w art. 6 o.p. definicję legalną podatku. Zgodnie z nią podatkiem jest publicznoprawne, nieodpłatne, przymusowe oraz bezzwrotne świadczenie pieniężne na rzecz Skarbu Państwa, województwa, powiatu lub gminy, wynikające z ustawy podatkowej. Powołana definicja oparta na elementach przedmiotowych, tzw. stałych cechach świadczenia podatkowego, i podmiotowych, wyznaczających „beneficjenta” tego typu świadczeń, niemal w pełni odzwierciedla stanowisko doktryny ${ }^{17} \mathrm{i}$ generalnie pozwala na odróżnienie tego typu daniny publicznej od pozostałych danin, w szczególności opłat, składek i ceł ${ }^{18}$.

${ }_{15}$ Por. I. Lipiec-Warzecha, Komentarz do art. 59 ustawy o finansach publicznych, s. 8.

${ }^{16}$ Choć ustawodawca nie używa identycznej terminologii, uznać należy, że na gruncie ustawy podobną funkcję pełni przepis art. 58 ust. 4, który upoważnia dysponentów części budżetowych lub dysponentów państwowych funduszów celowych do wyrażania zgody na niedochodzenie należności budżetu państwa z tytułu umów cywilnoprawnych, których kwota wraz z odsetkami nie przekracza 100 zł.

17 Według B. Brzezińskiego do tych cech należy jeszcze zaliczyć ogólność świadczenia i skutek zapłaty podatku w formie przewłaszczenia środków pieniężnych - por. B. Brzeziński, Zarys prawa finansów publicznych, Toruń 1997, s. 101.

${ }_{18}$ Por. R. Mastalski, E. Fojcik-Mastalska (red.), Prawo finansowe, Warszawa 2011, s. 132 i n.; A. Drwiłło (red.), Podstawy finansów i prawa finansowego, Warszawa 2011, s. 389 i n. 
Znacznie bardziej złożonej wykładni wymaga pojęcie „,niepodatkowe należności budżetowe", do którego odwołuje się zarówno ustawa - art. 60, jak i o.p. Ta ostatnia przepisem art. 3 pkt 8 wprowadza nawet jego definicję, ustalając, że rozumieć przez nie należy niebędące podatkami i opłatami należności stanowiące dochód budżetu państwa lub budżetu jednostki samorządu terytorialnego, wynikające ze stosunków publicznoprawnych. Istniejąca trudność w ustaleniu istoty prawnej niepodatkowych należności budżetowych (dalej: n.n.b.) stanowi również następstwo tego, że przepis art. 5 ust. 2 pkt 1 ustawy nie posługuje się omawianym pojęciem, a jednocześnie zalicza do danin publicznych ,inne świadczenia pieniężne", których obowiązek ponoszenia na rzecz państwa, jednostek samorządu terytorialnego, funduszów celowych oraz innych jednostek sektora finansów publicznych wynika z odrębnych ustaw. Jednoznacznej i wyczerpującej odpowiedzi na pytanie, co należy w świetle obowiązujących przepisów traktować jako n.n.b. nie udziela także przepis art. 60 ustawy. Należności tego rodzaju wymieniony przepis wskazuje, lecz nie czyni tego w sposób wyczerpujący, o czym świadczy użyty zwrot „w szczególności”. Katalog należności określony powołanym przepisem posiada zatem charakter katalogu otwartego ${ }^{19}$. Składają się nań bardzo różne rodzaje należności, których nie sposób jednoznacznie stypizować. Obok świadczeń o charakterze nieodpłatnym, np. kwoty dotacji podlegającej zwrotowi w przypadkach określonych w ustawie, znajdują się w nim: świadczenie o charakterze cywilnoprawnym, posiadające cechę odpłatności, tj. należności z tytułu gwarancji i poręczeń udzielonych przez Skarb Państwa i jednostki samorządu terytorialnego (dalej: JST) oraz świadczenia niezaliczane do żadnej z ww. grup, stanowiące konkretne źródło dochodu Skarbu Państwa lub JST. Do tych ostatnich należą: wpłaty nadwyżek środków finansowych agencji wykonawczych, wpłaty nadwyżek środków obrotowych samorządowych zakładów budżetowych, dochody pobierane przez państwowe i samorządowe jednostki budżetowe na podstawie odrębnych ustaw, a także pobrane przez JST dochody związane z realizacją zadań z zakresu administracji rządowej oraz innych zadań zleconych JST odrębnymi ustawami i nieodprowadzone na rachunek dochodów budżetu państwa - art. 60 pkt 3, 4, 7 i 8 . Z kolei przywołana definicja n.n.b. odwołuje się wprost, czego nie czynią ww. przepisy, do stosunków publicznoprawnych ${ }^{20} \mathrm{o}$ charakterze zobowiązaniowym ${ }^{21}$. Znaczy to, że mogą one wynikać wyłącznie ze stosunków prawnych, które w przeciwieństwie do stosunków cywilnoprawnych charakteryzuje brak

${ }^{19}$ Por. R. Suwaj, Wplyw ustawy z 27 sierpnia 2009 r. o finansach publicznych na zakres administracyjnego postępowania egzekucyjnego, „Finanse Komunalne” 2011, nr 3, s. 6.

${ }^{20}$ Według R. Trykozko należności te jeszcze przed przekazaniem ich do budżetu posiadają charakter środków publicznych - por. R. Trykozko, Ustawa o finansach publicznych. Komentarz dla jednostek samorzadu terytorialnego, Warszawa 2010, s. 146.

${ }^{21}$ Publicznoprawny charakter tego typu świadczeń potwierdza orzecznictwo, np. wyrok NSA z 18 marca 1999 r., I SA/Po 1565/98, LEX nr 37217 oraz wyrok NSA z dnia 24 lutego 2000 r., SA/ Bk 976/99, LEX nr 47667. 
równorzędności podmiotów w nich uczestniczących, zaś podstawą do kształtowania takich stosunków są przepisy powszechnie obowiązujące ${ }^{22}$, a nie wola stron, jak w przypadku umów"23.

Reasumując dotychczasowe rozważania, należałoby uznać, że n.n.b. powinny spełniać łącznie następujące warunki24:

1) nie posiadać cech podatku, opłaty 25

2) posiadać charakter publicznoprawny ${ }^{26}$;

3) rodzić stosunki prawne o charakterze zobowiązaniowym;

4) stanowić dochód budżetu państwa lub jednostki samorządu terytorialnego.

Świadczenia posiadające wszystkie wymienione cechy nie powinny być jednak traktowane jako szczególny i odrębny rodzaj daniny publicznej ${ }^{27}$. Z założenia posiadają one bowiem szeroki charakter i obejmują wszystkie publicznoprawne świadczenia, które nie mają cech podatków lub opłat, choć mogą być do nich konstrukcyjnie zbliżone ${ }^{28}$. Zdaniem L. Etela ${ }^{29} \mathrm{~W}$ ich granicach będą się zatem mieściły zarówno składki, odpisy, jak i wpisy oraz dopłaty ${ }^{30}$.

Przechodząc do charakterystyki ostatniego z wymienionych typów należności, „o charakterze cywilnoprawnym”, przede wszystkim należy wskazać,

${ }^{22}$ Zdaniem A. Huchli świadczenia publicznoprawne charakteryzuje to, iż podstawę ich przyznania i ustalenia stanowią akty prawa publicznego, a pozyskiwanie ma na celu zaspokojenie potrzeb publicznych - por. A. Huchla, Świadczenia, do których stosuje się Ordynacje podatkowa, [w:] R. Mastalski (red.), Księga jubileuszowa Profesora Marka Mazurkiewicza. Studia z dziedziny prawa finansowego, konstytucyjnego i ochrony środowiska, Wrocław 2001, s. 262 oraz E. Ruśkowski, [w:] idem (red.), Finanse publiczne i prawo finansowe, Warszawa 2000, t. 1, s. 13 i n.

${ }^{23}$ Cyt. za: S. Babiarz, B. Dauter, B. Gruszczyński, R. Hauser, A. Kabat, M. Niezgódka-Medek, Ordynacja podatkowa. Komentarz, Warszawa 2009, s. 43; por. także: B. Adamiak, J. Borkowski, R. Mastalski, J. Zubrzycki, Ordynacja podatkowa. Komentarz 2010, Warszawa 2010, s. 50; H. Dzwonkowski (red.), Ordynacja podatkowa 2011, wyd. 3, Warszawa 2011, s. 14.

${ }^{24}$ Por. M. Ślifirczyk, Niepodatkowe należności budżetowe - pojęcie i systematyka, „Gdańskie Studia Prawnicze. Studia Prawno-Finansowe" 2007, t. XVI, A. Drwiłło (red.), s. 337.

${ }^{25}$ Por. B. Brzeziński, M. Kalinowski, M. Masternak, A. Olesińska, Ordynacja podatkowa. Komentarz, Torun 2002, s. 11.

${ }^{26}$ Cecha ta może budzić wątpliwości w świetle należności wymienionej w art. 60 pkt 2 ustawy, której źródłem są czynności cywilnoprawne - por. R. Suwaj, op. cit., s. 7.

${ }^{27}$ Według M. Ślifirczyka jest to raczej pojęcie o charakterze technicznoprawnym, pozwalające na poddanie pewnego zbioru instytucji prawnych tym samym regulacjom - por. M. Ślifirczyk, op. cit., s. 337.

${ }^{28}$ Według R. Suwaja niepodatkowe należności o charakterze publicznoprawnym to wszelkie należności pieniężne i spodziewane dochody powstające na podstawie jednostronnego aktu administracyjnego, a ponadto należności wymienione w art. 60 ustawy - por. R. Suwaj, op. cit., s. 8.

${ }^{29}$ Por. L. Etel, Czy uchwaty rad gmin w sprawie renty planistycznej $i$ oplaty adiacenckiej sq w nadzorze regionalnych izb obrachunkowych?, „Finanse Komunalne” 2010, nr 3, s. 37; por. także: B. Brzeziński, M. Kalinowski, A. Olesińska, M. Masternak, J. Orłowski, Ordynacja podatkowa. Komentarz, Torun 2007, s. 27.

${ }^{30}$ Por. I. Czaja-Hliniak, Prawnofinansowa instytucja dopłat jako forma pozapodatkowych danin publicznych, Kraków 2006, s. 39 i n. 
iż w odróżnieniu od należności wcześniej przedstawionych przepisy ustaw nie zawierają definicji ani nie wyznaczają zakresów: podmiotowego i przedmiotowego tego pojęcia. Kierując się brzmieniem dotychczas przywołanych regulacji, należałoby w związku z tym przyjąć, że przedmiotowe należności pochodzą ze źródeł innych niż typowe należności podatkowe ${ }^{31}$ i n.n.b., lecz jednocześnie, że nie ma formalnych powodów, aby je wyłączać z kategorii dochodów publicznych (środków publicznych), o których mowa w przepisie art. 5 ust. 2 ustawy ${ }^{32}$. W rezultacie należałoby uznać, że należnościami cywilnoprawnymi są takie należności, które wynikają ze stosunków cywilnoprawnych kreowanych przy pomocy metody cywilnoprawnej zakładającej wolność i autonomię stron, sankcję majątkową i sądową drogę rozstrzygania sporów ${ }^{33}$. Mając powyższe na uwadze, należy się zgodzić z poglądem R. Szostaka, według którego tytułem prawnym do domagania się płatności tych należności może być nie tylko umowa, lecz także odszkodowanie i bezpodstawne wzbogacenie ${ }^{34}$. Gdyby jednak podjać próbę klasyfikacji przedmiotowych należności w oparciu o kryterium posiadania przez nie cech dochodu publicznego, przez który rozumie się dochód wynikający z innych tytułów niż zobowiązanie publicznoprawne o charakterze podatkowym bądź niepodatkowym, to okazałoby się, że mogą one przybierać wyjątkowo zróżnicowaną postać. Do tej grupy dochodów należałoby bowiem zaliczyć zarówno dochody z mienia, np. z najmu, dzierżawy i innych umów o podobnym charakterze (np. użytkowania wieczystego, leasingu), dywidendy z posiadanych praw majątkowych, jak i odsetki od środków na rachunkach bankowych, od posiadanych papierów wartościowych $^{35}$ lub kar umownych naliczanych w przypadku niewykonania lub nienależytego wykonania umowy ${ }^{36}$, a gdy chodzi o należności JST - należności za pobyt w szpitalu, dostawę wody, odbiór ścieków itp.

Kierując się treścią powołanych wyżej ustaw, przesłanki, od spełnienia których ustawodawca uzależnia udzielenie ulgi, należy podzielić zasadniczo na dwie kategorie, tj. przesłanki o charakterze formalnym oraz materialnym. Przesłanki zaliczane do pierwszej kategorii należy wiązać zarówno z oczekiwanym przez ustawodawcę zachowaniem dłużnika, jak i organów, do których należy decyzja w zakresie ich stosowania. Przede wszystkim należy jednak wskazać, iż przepisy ustawy i o.p. wyraźnie ograniczają z podmiotowego punktu widzenia kategorie należności, które mogą być przedmiotem ulgi. Są to zatem, zgodnie z przepi-

${ }^{31}$ Por. P. Smoleń (red.), Ustawa o finansach publicznych. Komentarz, Warszawa 2012, s. 418.

32 Por. E. Ruśkowski, J. M. Salachna (red.), Nowa ustawa o finansach publicznych wraz z ustawa wprowadzająca. Komentarz praktyczny, Gdańsk 2010, s. 201.

${ }_{33}$ Por. A. Stelmachowski, Zarys teorii prawa cywilnego, Warszawa 1998, s. 35 i n.

${ }^{34}$ Por. R. Szostak, op. cit., s. 48.

${ }^{35}$ Por. E. Ruśkowski, J. M. Salachna (red.), op. cit., s. 201; R. Szostak, op. cit., s. 48.

${ }^{36}$ Por. Ł. Jaroszewski, Stosowanie ulg w zakresie spłaty niepodatkowych należności jednostek samorzadu terytorialnego na podstawie ustawy z 29 sierpnia 2009 r. o finansach publicznych, „Samorząd Terytorialny" 2011, nr 1-2, s. 76. 
sem art. 55, należności przypadające wyłącznie organom administracji rządowej, państwowym jednostkom budżetowym lub państwowym funduszom celowym. Nie dotyczy to zatem należności przypadających innym jednostkom zaliczanym do sektora finansów publicznych - art. 9 ustawy, nawet jeżeli posiadałyby one status państwowej osoby prawnej lub państwowej jednostki organizacyjnej. Podobną konstrukcję prawną stosuje ustawodawca w przypadku należności przypadających samorządowi terytorialnemu. W tym wypadku należności, z płatnością których może być związana ulga, mogą wynikać z działalności dwóch ogólnie określonych kategorii podmiotów - JST ${ }^{37}$ i podległych im jednostek, np. jednostek budżetowych lub samorządowych zakładów budżetowych - art. 59.

Na tle przedstawionych rozwiązań nieco odmiennie wyznaczono zakres podmiotowy świadczeń w odniesieniu do n.n.b. i należności podatkowych, bowiem w odniesieniu do tych pierwszych, zgodnie z art. 60 ustawy, chodzi o dochody budżetu państwa albo jednostek samorządu terytorialnego, natomiast należności podatkowe przypadają w oparciu o cytowany przepis art. 6 o.p. odpowiednio Skarbowi Państwa, województwu, powiatowi lub gminie.

Do przesłanek o charakterze formalnym należy zaliczyć także wymóg wystąpienia przez dłużnika z wnioskiem o zastosowanie ulgi polegającej na umorzeniu należności w całości lub w części w razie zaistnienia choćby jednej przesłanki materialnej - art. 57 i 60 ust. 1 ustawy oraz art. 67a $\S 1$ o.p. Jako odstępstwo od zasady udzielania ulgi na wniosek należy natomiast traktować przepisy art. 56 oraz art. 59 ust. 3 i 4 ustawy, które w razie wystąpienia choćby jednego z typów zdarzeń określonych przepisem art. 56 upoważniają właściwy organ do podjęcia decyzji o zastosowaniu ulgi polegającej na umorzeniu należności o charakterze cywilnoprawnym. Podobne uprawnienia posiada organ podatkowy w razie wystąpienia któregokolwiek ze zdarzeń określonych przepisem art. 67d o.p.

Przesłanki materialne, których wystąpienie warunkuje uwzględnienie wniosku o udzielenie ulgi, nie posiadają jednorodnego charakteru. Stanowi to następstwo faktu, iż mimo że wszystkie one przybierają postać klauzul generalnych, to nie są tożsame w odniesieniu do omawianych rodzajów należności. Ponadto, ustawodawca w różnym zakresie uzależnia ocenę ich wystąpienia od stwierdzenia, czy w danym przypadku umorzenie byłoby równoznaczne z udzieleniem pomocy publicznej ${ }^{38}$.

${ }^{37}$ Nie ma zatem przeszkód, aby uznać, iż przepis ten znajduje zastosowanie do JST każdego szczebla oraz że w przeciwieństwie do przepisu art. 9 pkt 2 u.f.p. ustawodawca nie wiąże stosowania ulg z funkcjonowaniem związków JST.

38 Mowa o przepisach ustawy z dnia 30 kwietnia 2004 r. o postępowaniu w sprawach dotyczących pomocy publicznej, t.j. Dz. U. z 2007 r. Nr 59, poz. 404 ze zm. Por. M. Zdebel, Przestanki umarzania należności publicznoprawnych przedsiębiorców w świetle przepisów o warunkach udzielania pomocy publicznej, [w:] A. Pomorska, P. Smoleń, J. Stelmasiak, A. Gorgol (red.), Prawo finansowe w warunkach członkostwa Polski w Unii Europejskiej. Ksiegga jubileuszowa dedykowana Profesor Wandzie Wójtowicz, Lublin 2011, s. 451 i n. 
Redakcja przepisów art. 56 ust. 1 pkt 5, art. 67 ustawy oraz art. 67 a $\S 1$ o.p. zdaje się przekonywać, iż zamiarem ustawodawcy było wprowadzenie generalnej zasady, że organ, podejmując decyzje o stosowaniu ulg w płatności zobowiązań, w tym o umorzeniu, powinien kierować się „ważnym interesem podatnika, interesem publicznym" albo obiema przesłankami łącznie. W rzeczywistości jednak, jeżeli wziąć pod uwagę brzmienie przepisu art. 57 ustawy, należałoby uznać, że gdy przedmiotem umorzenia na wniosek zobowiązanego miałaby być część należności o charakterze cywilnoprawnym, decyzja o umorzeniu lub odmowie umorzenia powinna się opierać na stwierdzeniu istnienia innej przesłanki niż wymienione wyżej, choć także stanowiącej klauzulę generalną. Powołany przepis odwołuje się bowiem do wystąpienia „przypadków uzasadnionych względami społecznymi lub gospodarczymi, w szczególności zaś możliwościami płatniczymi dłużnika oraz uzasadnionym interesem Skarbu Państwa". W toku rozważań teoretycznych nie można wykluczyć, że w danym przypadku, gdy chodzi o omawiany typ należności, wystąpi każda $\mathrm{z}$ wymienionych przesłanek lub np. jedna z przesłanek oparta na interesie publicznym lub ważnym interesie zobowiązanego oraz przesłanka określona przepisem art. 57 ustawy. Literatura przedmiotu zdaje się jednak przywiązywać większą wagę do „konkurencji” przesłanek wymienionych przepisami art. 56 ust. 1 pkt 5 ustawy oraz art. $67 \mathrm{a} \S 1$ o.p. Nie wdając się w szczegółowe rozważania, autor opracowania reprezentuje w tym zakresie pogląd, że prowadzenie analiz na temat konkurencji ww. przesłanek w świetle obowiązującego stanu prawnego nie znajduje podstaw. Przeciwko temu przemawia przede wszystkim wykładnia językowa ww. przepisów, w szczególności użycie przez ustawodawcę wyrażenia „lub”. Zaprezentowany pogląd znajduje oparcie w literaturze przedmiotu, choć jednocześnie podkreśla się, iż przydanie przez organ podatkowy w konkretnej sprawie większej rangi interesowi publicznemu nie da się wykluczyć, lecz zawsze powinno być jednoznacznie i przekonująco uzasadnione ${ }^{39}$.

Niezależnie od rodzaju przesłanki, decyzje organów dotyczące zastosowania ulgi opierają się na „uznaniu administracyjnym”. Oznacza to, że w przypadkach postępowań z udziałem tych organów dysponują one możliwością dokonania wyboru konsekwencji prawnych zaistniałej sytuacji (stwierdzonego stanu faktycznego), do której odnosi się hipoteza wskazanych norm prawnych ${ }^{40}$. Innymi słowy, organ podejmujący decyzje w sprawie udzielenia ulgi nie jest zobligowany do jej udzielenia, zaś ocena dokonywana przez ten organ zarówno co do tego, czy zaistniały przesłanki oraz jaki jest ich wpływ na podjęcie decyzji w sprawie udzielenia

${ }^{39}$ Por. B. Brzeziński, M. Kalinowski, A. Olesińska, M. Masternak, J. Orłowski, op. cit., s. 471; wyrok NSA z 30 października 2002 r., III SA 668/01 - niepublikowany oraz wyrok NSA z 30 maja 2001 r., III SA 830/00, „Monitor Podatkowy” 2001, nr 9, s. 2.

${ }_{40}$ Por. B. Brzeziński, M. Kalinowski, A. Olesińska, M. Masternak, J. Orłowski, op. cit., s. 464. 
bądź odmowy udzielenia ulgi, oparty jest na elementach natury słusznościowej ${ }^{41}$. Stanowisko to jest zgodne ze stanowiskiem judykatury ${ }^{42}$.

Prezentowany pogląd nie oznacza oczywiście, że uznanie administracyjne, na podstawie którego organy podejmują decyzje, posiada charakter nieograniczony $^{43}$.

Ze względu na cele stawiane niniejszemu opracowaniu szczegółowa analiza treści wskazanych przesłanek wykracza poza granice wyznaczone jego tematem, nie budzi jednak wątpliwości fakt, iż ich konstrukcja prawna uzasadnia pogląd, że mamy w tym wypadku do czynienia $\mathrm{z}$ przesłankami wyrażonymi w sposób nieostry ${ }^{44}$. Nieostrość ta wymusza ich wielopłaszczyznowe ujęcie ${ }^{45}$. Jest to szczególnie widoczne w zakresie przesłanki ,interesu publicznego” oraz „ważnego interesu podatnika", czemu daje wyraz treść orzeczeń zapadłych przed sądami administracyjnymi, np. w tezach wyroków NSA z dnia 12 lutego 2003 r., III SA 1838/0146 oraz z dnia 6 lipca 2005 r., I SA/Bk 134/057, w myśl których nakaz uwzględnienia interesu publicznego oznacza dyrektywę postępowania nakazującą mieć na uwadze respektowanie wartości wspólnych dla całego społeczeństwa, takich jak sprawiedliwość, bezpieczeństwo, zaufanie obywateli do organów władzy, sprawność działania aparatu państwowego, korektę błędnych decyzji ${ }^{48}$. Gdy mowa o drugiej z wymienionych przesłanek materialnych, wychodząc ze słownikowego znaczenia nadawanego słowu ,interes"49, należałoby przyjąć, że rozumie się go najczęściej jako określenie pożytku, czyjegoś dobra i korzyści.

${ }^{41}$ Por. B. Adamiak, J. Borkowski, R. Mastalski, J. Zubrzycki, Ordynacja podatkowa. Komentarz, Warszawa 2003, s. 274.

${ }^{42}$ Por. wyrok SN z 8 listopada 1996 r., III RN 24/96, „Przegląd Orzecznictwa Podatkowego” 1999, nr 21, poz. 6; wyrok NSA z 15 lutego 1984 r., SA/Wr 8/84, „Przegląd Orzecznictwa Podatkowego” 1992, nr 2, poz. 31; wyrok NSA z 24 kwietnia 2001 r., I SA/Ka 498/00, „Prawo Przedsiębiorcy” 2001, nr 45, s. 14; por. także: wyrok NSA z 1 czerwca 1981 r., SA 820/81, „Orzecznictwo Naczelnego Sądu Administracyjnego” 1981, nr 1, poz. 57 z glosą aprobującą J. Łętowskiego, „Orzecznictwo Sądów Polskich i Komisji Arbitrażowych” 1981, nr 1-2, poz. 22 oraz A. Bartosiewicz, R. Kubacki, Ulgi platnicze w świetle wartości konstytucyjnych, „Monitor Podatkowy” 2007, nr 12, s. 47; wyrok WSA z 23 października 2006 r., III SA/Wa 2007/06, [za:] A. Bartosiewicz, R. Kubacki, op. cit., s. 47.

43 Por. A. Gomułowicz, J. Małecki, Podatki i prawo podatkowe, Poznań 1998, s. 246; L. Guzek, Umorzenie zaległości podatkowej a kognicja NSA, „Monitor Podatkowy” 2002, nr 2, s. 25; B. Rutkowski, Kompetencje uznaniowe, cz. 1, „Doradca Podatnika” 1998, nr 25, s. 27.

${ }^{44}$ Por. R. Mastalski, Prawo podatkowe, Warszawa 2006, s. 44.

${ }^{45}$ Por. A. Wróbel, Interes publiczny w postępowaniu administracyjnym, [w:] J. Szreniawski (red.), Administracja publiczna u progu XX wieku: prace dedykowane prof. zw. dr. hab. Janowi Szreniawskiemu z okazji jubileuszu 45-lecia pracy naukowej, Przemyśl 2000, s. 701.

46 „Monitor Podatkowy” 2003, nr 7, poz. 43.

47 Za: A. Bartosiewicz, R. Kubacki, op. cit., s. 49.

${ }^{48}$ Por. B. Brzeziński, M. Kalinowski, A. Olesińska, Ordynacja podatkowa. Komentarz. Zobowiazania podatkowe, Torun 1999, s. 240 i n.; E. Ruśkowski (red.), Finanse publiczne ..., t. 2, s. 148.

${ }_{49}$ Por. M. Szymczak (red.), Stownik języka polskiego, t. I, Warszawa 1983, s. 799. 
Odpowiada to generalnie rozumieniu tego terminu także w języku prawnym i prawniczym ${ }^{50}$. W rezultacie, mówiąc o interesie dłużnika, należałoby przyjąć, iż będzie to stan oczekiwania przez niego zachowania posiadanych już korzyści lub wyczekiwanie na pojawienie się pewnego dobra ${ }^{51}$.

Analiza orzeczeń sądów administracyjnych zapadłych w okresie od końca lat 80. ubiegłego wieku do chwili obecnej prowadzi do wniosku, że najczęstszym argumentem i okolicznością, która ma przemawiać za istnieniem przedmiotowej przesłanki, jest trudna sytuacja ekonomiczna, w której znalazł się podatnik. Stanowisko takie judykatura zdaje się nawet preferować. Dla przykładu wskazać należy tezę wyroku NSA z dnia 14 października 1999 r., III SA $7542 / 98^{52}$, w myśl której kondycja finansowo-ekonomiczna podmiotu ubiegającego się o umorzenie zaległości podatkowej jest okolicznością pierwszoplanową z punktu widzenia przesłanek określonych w art. 67a $§ 1$ o.p. (dawniej 67) oraz wyroku WSA we Wrocławiu z dnia 22 listopada 1995 r., SA/Wr 622/9553, wedle którego przesłankami dla podjęcia decyzji o rozłożeniu należności na raty są: trudna sytuacja materialna lub zagrożenie egzystencji podatnika ${ }^{54}$.

Obok wymienionych sytuacji drugą zasadniczą kategorią zdarzeń, z którymi judykatura wiąże wystąpienie omawianej przesłanki, jest wystąpienie szeroko rozumianych klęsk żywiołowych lub nadzwyczajnych przypadków losowych. Potwierdzają to tezy wyroków NSA z dnia 28 stycznia 2000 r., III SA 181/9955, z dnia 3 marca 1998 r., III SA 1127/8756 oraz z dnia 22 kwietnia 1999 r., SA/Sz $850 / 98^{57}$.

Wskazane przykłady interpretacji pojęcia ,interes” pozwalają na sformułowanie wniosku, że temu pojęciu nie można przypisać uogólniającego znaczenia opisowego i wymaga ono permanentnej redefinicji.

${ }^{50}$ Por. J. Orłowski, Przesłanki umorzenia zaległości podatkowych w ordynacji podatkowej, „Radca Prawny”, nr 4, s. 93; Z. Rybicki (red.), Mała Encyklopedia Prawa, Warszawa 1980, s. 162.

${ }^{51}$ Por. S. Presnarowicz, Zwolnienia i ulgi uznaniowe w indywidualnych sprawach - przestanki rozstrzygnięć, „Przegląd Podatkowy” 1998, nr 7, s. 30.

52 Por. K. Baran, Trudna sytuacja ekonomiczna podatnika jako przestanka rozłożenia na raty bąź umorzenia zaległości podatkowej lub odsetek za zwłokę, „Doradztwo Podatkowe” 2002, nr 3, s. 31. Element ograniczenia zdolności płatniczej podatnika oraz konieczności istnienia związku pomiędzy obniżeniem tej zdolności a zajściem wypadków powodujących i uzasadniających niemożność zapłaty eksponuje wyrok NSA z 26 listopada 1999 r., I SA/Łd - niepublikowany; por. także wyrok NSA z 18 lutego 2000 r., III Sa 372/99, [za:] K. Dworniak, Ordynacja podatkowa. Komentarz, Warszawa 2003, s. 111.

${ }_{53}$ Por. K. Baran, op. cit., s. 31.

${ }^{54}$ Do tej samej kategorii zdarzeń należałoby zaliczyć brak możliwości zarobkowania czy utratę losową majątku - wyrok NSA z 22 kwietnia 1999 r., SA/Sz 850/98, [za:] C. Kosikowski, H. Dzwonkowski, A. Huchla, Ustawa Ordynacja podatkowa. Komentarz, Warszawa 2004, s. 240; por. także wyrok NSA z 17 marca 1994 r., SA/Po 3579/93, „Wspólnota” 1994, nr 39, s. 14.

${ }_{55}$ Za: K. Dworniak, op. cit., s. 112.

56 „Przegląd Orzecznictwa Podatkowego” 1992, nr 2, poz. 40.

57 „Przegląd Orzecznictwa Podatkowego” 2000, nr 6, poz. 168. 
Analizując przesłanki materialne stosowania ulg w płatności należności, wskazać również należy przesłankę wynikającą z przepisu art. 57 ustawy. Porównanie ww. przesłanki z wcześniej przedstawionymi - „interes publiczny” i „ważny interes dłużnika” - prowadzi do wniosku, iż i w tym wypadku ustawodawca posłużył się zwrotem niedookreślonym ${ }^{58}$. Zatem interpretację treści przedmiotowej przesłanki należy również oprzeć na indywidualnej ocenie każdego przypadku. Ponadto i w takich razach należy odwoływać się do stanowiska judykatury prezentowanego w sprawach ulg podatkowych. Jako reprezentatywne w tym zakresie należy wskazać tezy kilku orzeczeń NSA. I tak, zgodnie z tezą wyroku NSA we Wrocławiu z dnia 28 września 1999 r. uwzględnienie wniosku o umorzenie zaległości podatkowych lub odsetek za zwłokę jest możliwe tylko wówczas, gdy jest to uzasadnione względami gospodarczymi i społecznymi ${ }^{59}$. Do konkretnych sytuacji obrazujących sytuację finansową podatnika odwołuje się natomiast wyrok NSA w Łodzi z dnia 18 czerwca 1999 r., według którego brak środków na pokrycie niezbędnych wydatków bieżących, koniecznych do utrzymania rodziny, w tym małoletnich dzieci, spowodowany niskimi dochodami, może być w określonych okolicznościach uznany za wypadek społecznie uzasadniony ${ }^{60}$. Do tej samej kategorii orzeczeń należy niewątpliwie zaliczyć także wyrok NSA w Katowicach z dnia 18 grudnia 1998 r., który stwierdza, że zaległości podatkowe mogą być umarzane w wypadkach gospodarczo i społecznie uzasadnionych, a za taką sytuację można uznać znaczne obniżenie zdolności płatniczej podatnika spowodowane klęską lub innym wypadkiem losowym, a także podważenie w istotny sposób warunków egzystencji jego rodziny lub spowodowanie upadku przedsiębiorstwa bądź prowadzonego zakładu w wyniku spłaty lub wyegzekwowania zaległości podatkowych ${ }^{61}$.

Rozważania podjęte w pracy pozwalają na sformułowanie następujących wniosków:

1. Posługiwanie się przez ustawodawcę nieostro określonymi przesłankami materialnymi uzasadniającymi udzielenie ulgi w formie umorzenia całości lub części zobowiązania jest uzasadnione, albowiem uregulowanie przepisami w sposób jednoznaczny i wyczerpujący sytuacji uzasadniających jej zastosowanie jest praktycznie niemożliwe, sprzyja natomiast przystosowaniu prawa do poszczególnych przypadków bez potrzeby zmiany obowiązujących przepisów ${ }^{62}$.

${ }^{58}$ Zwrotami o identycznym brzmieniu ustawodawca posłużył się w ustawie z dnia 19 grudnia 1980 r. o zobowiązaniach podatkowych, Dz. U. Nr 27, poz. 111 ze zm.

59 Sygn. I SA/Wr 131/ 97, LEX nr 39005.

${ }^{60}$ Sygn. I SA/Łd 1120/97, LEX nr 38069.

${ }^{61}$ Sygn. I SA/Ka 1262/96, LEX nr 32 151; por. także wyrok NSA w Lublinie z 20 listopada 1998 r., I SA/Lu 803/98, LEX nr 37133.

62 Por. W. Grygorowicz, Umorzenie zaległości podatkowych, „Glosa” 1998, nr 7, s. 3. 
2. O istnieniu „ważnego interesu zobowiązanego" powinny decydować każdorazowo zobiektywizowane kryteria, zgodnie z powszechnie aprobowaną hierarchią wartości ${ }^{63}$.

3. Wykorzystywanie przesłanki „interes publiczny” jest uzasadnione, choć jej stosowanie jest możliwe tylko poprzez konkretyzację indywidualnych przypadków, z jednoczesnym uwzględnieniem kierunkowych celów i wartości rządzących procesem stosowania prawa ${ }^{64}$.

${ }^{63}$ Por. S. Babiarz, B. Dauter, B. Gruszczyński, R. Hauser, A. Kabat, M. Niezgódka-Medek, op. cit., s. 382.

${ }^{64}$ Por. B. Dauter, Nieefektywne sposoby wygasania zobowiązań podatkowych, „Doradztwo Podatkowe" 2002, nr 6, s. 51. 